Georgia State University

ScholarWorks @ Georgia State University

1995

\title{
The status of local smoking regulations in North Carolina following a state preemption bill
}

\author{
Elizabeth Conlisk \\ Hampshire College \\ Michael Siegel \\ Boston University \\ Eugene Lengerich \\ Pennsylvania State University - Main Campus \\ William Mac Kenzie \\ Sally Malek
}

See next page for additional authors

Follow this and additional works at: https://scholarworks.gsu.edu/iph_facpub

Part of the Public Health Commons

\section{Recommended Citation}

Conlisk, E., Siegel, M., Lengerich, E., MacKenzie, W., Malek, S., and Eriksen, M.P. (1995). The status of local smoking regulations in North Carolina following a state preemption bill. Journal of the American Medical Association, 273(10): 805-807.

This Article is brought to you for free and open access by the School of Public Health at ScholarWorks @ Georgia State University. It has been accepted for inclusion in Public Health Faculty Publications by an authorized administrator of ScholarWorks @ Georgia State University. For more information, please contact scholarworks@gsu.edu. 
Authors

Elizabeth Conlisk, Michael Siegel, Eugene Lengerich, William Mac Kenzie, Sally Malek, and Michael Eriksen

This article is available at ScholarWorks @ Georgia State University: https://scholarworks.gsu.edu/iph_facpub/61 


\title{
The Status of Local Smoking Regulations in North Carolina Following a State Preemption Bill
}

\author{
Elizabeth Conlisk, PhD; Michaei Siegel, MD; Eugene Lengerich, VMD; William Mac Kenzie, MD; \\ Sally Malek, MPH; Michael Eriksen, ScD
}

Objective.-To determine the number and protectiveness of local smoking regulations adopted before the implementation of a preemptive statewide smoking control bill.

Method.-Review of local smoking control regulations from all 100 counties and 85 municipalities with populations greater than 5000 in North Carolina.

Main Outcome Measures.-Adoption of local smoking control regulations before and during the 3-month delay in enactment of the preemptive bill. Protectiveness of regulations was based on restrictions on smoking and requirements for separate ventilation systems at private work sites: none (smoking unrestricted); minimal (smoking restricted to designated areas); partial (smoking restricted to designated areas served by separate ventilation systems); and complete (smoking prohibited). Because some regulations would be phased in gradually over the next 5 years, we evaluated the requirements that will be in effect by January 1, 2000 .

Results.-Between July 15 and October 15, 1993, the number of local smoking regulations in North Carolina increased from 16 to 105 . By the year $2000,59 \%$ of private employees still will not be guaranteed any protection from work site environmental tobacco smoke; $19 \%$ will have minimal protection, $22 \%$ will have partial protection, and none will have complete protection.

Conclusions. - The 3-month delay in preemption created an unnatural time frame for communities to organize, debate, and adopt smoking restrictions. Despite the adoption of 89 new regulations, no private employees will be guaranteed complete protection from work site environmental tobacco smoke by the year 2000; new regulations can no longer be adopted. HB 957 has been a setback for public health in North Carolina.

(JAMA. 1995;273:805-807)

From the North Carolina Department of Environment, Health, and Natural Resources, Office of Epidemiology, Health, and Naturai Resources, Office of Epidemiology,
Division of Adult Health Promotion, Raleigh (Drs Conlisk and Lengerich and Ms Malek); and the Division of Field Epidemiology, Epidemiology Program Office (Drs Conlisk and Mac Kenzie), Epidemic Intelligence Service (Drs Conlisk and Siegel), Office of Smoking and Health (Drs Siegel and Eriksen) Surveillance and Analysis (Dr Lengerich), National Center for Chronic Disease Prevention and Health Promotion, Centers for Disease Control and Prevention, Atlanta, Ga.

Reprint requests to North Carolina Department of Environment, Health, and Natural Resources, Office of Epidemiology, Division of Adult Health Promotion, PO Box 27687, Raleigh, NC 27611-7687 (Dr Conlisk). adopted regulations that specifically prohibit work site smoking; in contrast, no state had legislated such a ban. ${ }^{6}$

The success of local bans has prompted the tobacco industry to support smoking control legislation at the state level that preempts local regulations that are more restrictive. ${ }^{7,8}$ These bills are usually promoted as prohealth measures that guarantee a minimum uniform set of restrictions for all communities. However, the restrictions are usually very weak, and local governments are prevented from adopting more restrictive measures in the future. To date, preemptive smoking control legislation has been enacted in 16 states including North Carolina, the leading tobacco-producing state in the country (Centers for Disease Control and Prevention, Office on Smoking and Health, unpublished data, 1994) ${ }^{9}$

North Carolina's preemption bill, HB 957, was enacted by the General Assembly on July $15,1993 .^{10}$ Its main requirement was that smoking be permitted in at least $20 \%$ of space in statecontrolled buildings. Nonsmoking areas were not required. More important, the bill prohibited local regulatory boards from adopting more restrictive regulations for public or private buildings after October 15, 1993; local regulations adopted before that date would be grandfathered in. During the 3-month period between July 15 and October 15, 1993, smoking regulations were proposed in more than half of the counties in North Carolina, prompting the media to declare HB 957 an unexpected victory for tobacco control. ${ }^{11}$ 
Table 1.-Classification of Local Smoking Regulations by Level of Protection From Environmental Tobacco Smoke (ETS) at Private Work Sites

\begin{tabular}{lc}
$\begin{array}{c}\text { Level of } \\
\text { Protection } \\
\text { From ETS }\end{array}$ & \multicolumn{1}{c}{ Criteria } \\
\hline None & $\begin{array}{c}\text { No smoking restrictions for private } \\
\text { work sites } \\
\text { Minimal } \\
\text { areas; separate HVAC* system } \\
\text { not required } \\
\text { Smoking restricted to designated } \\
\text { areas; separate HVAC system } \\
\text { required }\end{array}$ \\
Complete & Smoking prohibited
\end{tabular}

*Heating, ventilation, and air-conditioning.

We report herein the number of regulations adopted before and during this 3 -month period and evaluate the extent to which these regulations will provide protection from ETS at private work sites.

\section{Methods}

Local smoking regulations were compiled for all 100 counties and the $85 \mathrm{mu}$ nicipalities with populations greater than 5000 in North Carolina. A local smoking regulation was defined as a county or city ordinance or a board of health regulation that restricts smoking in any public or private place. In North Carolina, county ordinances apply only to the unincorporated areas of counties, and city ordinances apply only to incorporated areas. Board of health regulations apply to both the incorporated and unincorporated areas of the county(s) where the board has jurisdiction. In counties and cities where both an ordinance and a board of health regulation were adopted, the more restrictive regulation applies.

We learned of all smoking regulations by contacting the 85 boards of health. 100 boards of county commissioners, and 85 city councils by mail, asking if and when a smoking control regulation(s) had been adopted. Nonrespondents were contacted by telephone. Copies of all regulations were obtained and were classified by the date (quarter) of adoption. The four quarters were defined to begin on the dates January 15, April 15, July 15 , and October 15 , so that the 3 -month delay in preemption following HB 957 constituted one complete quarter.

To determine protectiveness, we examined requirements for nonsmoking areas and for separate heating, ventilation, and air-conditioning (HVAC) systems at private work sites. We focused on private work sites because they employ approximately $83 \%$ of the nonagricultural workforce in North Carolina. ${ }^{2}$ Regulations were classified into four levels of protection (Table 1): none (no restrictions on smoking); minimal (smok-

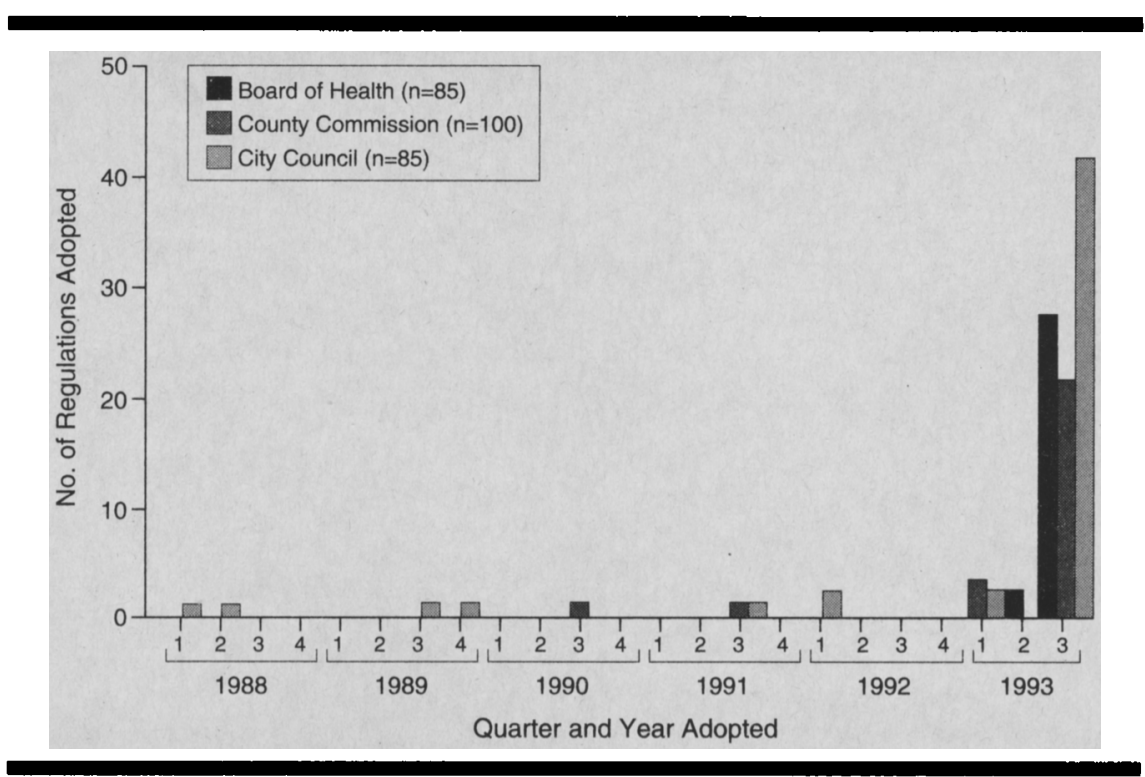

Number of local smoking regulations adopted per quarter in North Carolina, by regulatory board. HB 957 was adopted at the beginning of the third quarter of 1993 .

Table 2.-Protectiveness of Local Smoking Regulations* Adopted in North Carolina by Regulatory Boards

\begin{tabular}{lcccc}
\multicolumn{1}{c}{ Regulatory Board } & None & Minimal & Partial & Complete \\
\hline Boards of health $(n=85), \%$ & 76 & 11 & 13 & 0 \\
\hline County commissions $(n=100), \%$ & 98 & 2 & 0 & 0 \\
\hline City councils $(n=85), \%$ & 96 & 3 & 1 & 0 \\
\hline
\end{tabular}

*Effective on or before January 1, 2000.

ing restricted to designated areas; separate $\mathrm{HVAC}$ system not required); partial (smoking restricted to designated areas; separate HVAC system required); and complete (smoking prohibited). Some regulations are scheduled to be phased in over the next 5 years; therefore, each regulation was classified by the requirements that will be in effect by the last phase-in date: January 1 , 2000 . All regulations were classified by two reviewers (E.C. and M.S.) who were in $100 \%$ agreement with the classifications given.

To calculate the percentage of private employees that will be covered by each degree of protection at their work site, we used data on the number of nonagricultural, private employees in each incorporated and unincorporated area in North Carolina. ${ }^{12}$

\section{Results}

Between January 1, 1988, and July 15, 1993 , a total of 16 local smoking regulations were adopted in North Carolina: two by boards of health, five by county commissions, and nine by city councils (Figure). These regulations were adopted on a sporadic basis, with a slight rise following the release of the Environmental Protection Agency's report on ETS in January $1993 .^{3}$ In the quarter following the adoption of HB 957,89 more regulations were adopted: 27 by boards of health, 21 by county commissions, and 41 by city councils. Eighty-eight of these 89 regulations were the first smoking control measures ever adopted by the respective regulatory board.

Most regulatory boards did not adopt any smoking restrictions for private work sites - either they did not adopt a smoking regulation, or the regulations they adopted did not include any requirements that pertain to private work sites (Table 2). Twenty-four percent of boards of health adopted regulations that met the criteria for minimal or partial protection, compared with only $2 \%$ of county commissions and $4 \%$ of city councils. No regulatory board adopted regulations that met the criteria for complete protection.

By the year 2000, when all regulations will have gone into effect, $59 \%$ of the 2.6 million private employees in North Carolina will still not be guaranteed any legal protection from ETS at their work site; $19 \%$ will have minimal protection, $22 \%$ will have partial protection, and $0 \%$ will have complete protection.

\section{Comment}

North Carolina's preemption bill, HB 957 , included an unusual legislative compromise that gave local regulatory 
boards 3 months to adopt smoking restrictions that would be grandfathered in. During this 3-month interim, the number of local smoking regulations in North Carolina increased from 16 to 105 . As of January 1,2000, when all requirements will be in effect, $59 \%$ of private employees will still not be guaranteed any protection from work site ETS. Nineteen percent will be guaranteed minimal protection. Although their work sites will be required to have a nonsmoking area, this area will not be required to have a separate HVAC system. After 1 hour of air mixing, the average concentration of ETS will be approximately the same in the smoking and nonsmoking areas. ${ }^{13-15}$ Twenty-two percent will be guaranteed partial protection. Although smoking areas in their work sites will be required to have separate HVAC systems, these areas could be work areas that must be frequented by nonsmokers. Furthermore, even properly maintained systems that meet strict ventilation standards

\section{References}

1. The Health Consequences of Involuntary Smoking: A Report of the Surgeon General. Washington, DC: US Dept of Health and Human Services; 1986. 2. Environmental Tobacco Smoke in the Workplace: Lung Cancer and Other Health Effects. Cincinnati, Ohio: National Institute for Occupational Safety and Health; 1991. US Dept of Health and Human Services publication NIOSH 91-108. 3. Respiratory Health Effects of Passive Smoking: Lung Cancer and Other Disorders. Washington, DC: Environmental Protection Agency; 1992. Publication EPA/600/6-90/006F.

4. Repace JL, Lowrey AH. A quantitative estimate of nonsmokers' lung cancer risk from passive smoking. Environ Int. 1985;11:3-22.

5. US Public Health Service. Healthy People 2000: National Health Promotion and Disease Prevention Objectives. Washington, DC: US Dept of Health and Human Services, 1991. DHHS publication PHS 91-50212. have been shown to leak ETS, as evidenced by ambient nicotine levels in nonsmoking areas. ${ }^{16,17}$ The only regulations that provide complete protection are those that ban smoking in all work areas. Given this criterion, no private employees will be guaranteed complete protection from work site ETS by the year 2000.

Although HB 957 appears to have prompted many communities to adopt smoking control regulations for the first time, the 3-month deadline created an unnatural time frame for communities to organize, debate, and adopt restrictions for the indefinite future. The adoption of smoking control laws is normally an incremental process with increasingly protective measures being adopted over time; rarely does a community adopt a comprehensive measure as its first law. In North Carolina, preemption is now in effect and local regulatory boards cannot take further steps to protect employees from work site ETS. Although HB 957

6. 100\% Smokefree Ordinances. Berkeley, Calif: Americans for Nonsmokers' Rights; 1994.

7. Jacobsen PD, Wasserman J, Raube K. The politics of antismoking legislation.J Health Polit Policy Law. 1993;18:787-819.

8. Major Local Tobacco Control Ordinances in the United States. Bethesda, Md: US Dept of Health and Human Services; 1993. National Institutes of Health publication 93-3532, Monograph 3.

9. North Carolina Agricultural Statistics. 1989. North Carolina Dept of Agriculture publication 166, 9-89-7500.

10. House Bill 957: An Act to Regulate Smoking in Public Places. Legislative Services Office of the North Carolina General Assembly; 1993.

11. Snatching defeat from the jaws of victory. $R a$ leigh News \& Observer. September 9, 1993:1F, 7F. 12. Employment and Wages in North Carolina, 1992. Raleigh: Employment Security Commission of North Carolina; 1994. Labor Market Information could be repealed, efforts to repeal preemptive smoking control legislation in other states have not been successful (Centers for Disease Control and Prevention, Office on Smoking and Health, unpublished data, 1994)

The impact of preemption on public health goes beyond its impact on the number and protectiveness of local regulations. Local smoking regulations generate public debate and community organization around the issue of ETS. Through this process, the public is educated and the social norms regarding tobacco use may change. By preventing new regulations from being adopted, preemption blocks an effective means of educating the public.

Rather than a victory for tobacco control, HB 957 has been a setback for public health in North Carolina.

The authors gratefully acknowledge the assistance of J. Dale Simmons, MD, Leslie Brown, JD, and Len Paulozzi, MD, for their thorough and thoughtful review of the manuscript.

\section{ES-202}

13. Repace JL, Lowrey AH. An indoor air quality standard for ambient tobacco smoke based on car cinogenic risk. N Y State J Med. 1985;85:381-383. 14. Lefcoe NM, Ashley MJ, Pederson LL, Keays JJ. The health risks of passive smoking: the growing case for control in enclosed environments. Chest. 1983;94:90-95.

15. Olshansky SJ. Is smoker/nonsmoker segregation effective in reducing passive inhalation among nonsmokers? Am J Public Health. 1982;72. 737-739.

16. Repace JL. Risk management of passive smoking at work and at home. St Louis Law Rev. 1994; 13:763-785.

17. Vaughan WM, Hammond SK. Impact of a 'designated smoking area' policy on nicotine vapor and particle concentration in a modern office building. $J$ Air Wast Manage Assoc. 1993;40:1012-1017. 